\title{
Beastly Neighbors: Continuing Relations in Cattle Country
}

\author{
Order Without Law: How Neighbors Settle Disputes. By Robert C. Ellickson." \\ Cambridge, MA: Harvard University Press, 1991. Pp. ix, 292. \$39.95 (cloth).
}

Barbara Yngvesson ${ }^{\dagger}$

\section{INTRODUCTION}

Robert Ellickson's Order Without Law tells a familiar American tale of law avoidance by middle-class neighbors. ${ }^{2}$ The characters of Ellickson's story, which is set in Shasta County, California, are cattlemen who own and operate large family ranches, and owners of smaller "ranchettes"-retirees and other recent settlers who came to Northern California from urban areas to the south. Ellickson describes the relations of cattlemen and ranchette owners in the context of incidents involving stray cattle, which are owned by ranchers but often found on the property of ranchette owners or on nearby highways, where cattle and drivers are often seriously injured and even killed by collisions. In his account, the way these incidents are handled reveals an order of neighborliness that exists without regard to the law. Using Ellickson's fieldwork, this Book Review offers an alternative interpretation of neighborliness. I argue that law and other social forces are not separable-distinct in theory, albeit hybrid in practice. Law and neighborliness are

* Walter E. Meyer Professor of Property and Urban Law, Yale Law School.

$\dagger$ Professor of Anthropology, Hampshire College. I thank Marlene Gerber Fried and Maureen A. Mahoney for comments on an earlier draft of this Book Review.

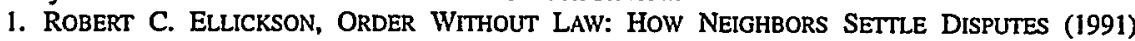
[hereinafter cited by page number only].

2. For other accounts of avoidance of formal law, see CAROL J. GREENHOUSE, PRAYING FOR JUSTICE: FAITH, ORDER, AND COMMUNITY IN AN AMERICAN TOWN (1986); David M. Engel, The Oven Bird's Song: Insiders, Outsiders, and Personal Injuries in an American Community, 18 LAW \& Soc'Y REV. 551 (1984); Sally E. Merry \& Susan S. Silbey, What Do Plaintiffs Want?: Reexamining the Concept of Dispute, 9 JuST. SYS. J. 151 (1984); Barbara Yngvesson, Making Law at the Doorway: The Clerk, the Court, and the Construction of Community in a New England Town, 22 LAW \& SOC'Y REV. 409 (1988). Greenhouse, and Merry and Silbey, describe middle- and working-class communities in the eastern and southern United States where "virtue" is incompatible with court use; Engel discusses the avoidance of formal law among people who define themselves as part of the same informally interacting social group, but notes as well the recourse to law when this system breaks down; Yngvesson describes the ideology of restraint and conflict avoidance that shapes the efforts of a court clerk in resolving neighborhood conflicts. 
both dimensions of the social regime of Shasta County, a regime that is shaped through the everyday relations of cattlemen, farmers, county supervisors, brand inspectors, and others.

Ellickson undertook his research in order to test the Coase Theorem ${ }^{3}$ in a real-world setting. This theorem, central to scholarship in law and economics, begins with the premise that people will bargain to mutual advantage from legally established entitlements. Coase used what Ellickson terms the "Parable of the Farmer and the Rancher"4 as his paradigmatic example of cooperative bargaining. As Ellickson restates the point,

making a rancher liable for damage done by his trespassing cattle would not cause the rancher to reduce the size of his herds, erect more fencing, or keep a closer watch on his livestock. A rancher who is liable for trespass damage has a legal incentive to implement all cost-justified measures to control his cattle. But even if the law were to decline to make the rancher liable, Coase reasoned that potential trespass victims would pay the rancher to implement the identical trespass-control measures.

Order Without Law examines the actual behavior of farmers (ranchette owners) and ranchers in Shasta County. Ellickson concludes that the Coase Theorem is both right and wrong: Coase was correct when he predicted that people will cooperate to mutual advantage, regardless of a change in formal rules of liability; but Coase was wrong in his assumption that the farmer and the rancher will bargain from "legally established entitlements." Rather, Ellickson maintains, farmers and ranchers achieve cooperative outcomes "by developing and enforcing adaptive norms of neighborliness that trump formal legal entitlements." $\mathrm{He}$ describes these norms as "nonhierarchical processes of coordination"7 and argues that neighborliness is shaped "beyond the reach of law."

In developing his critique, Ellickson makes an important move away from the ideology of legal centralism, which dominates scholarly work in law and economics and shapes policy debates about the place of formal law in everyday life. Legal centralists believe both that the state is the fundamental basis of political organization and that law constitutes a unified hierarchical system of norms. ${ }^{9}$ By demonstrating that the ranchers and ranchette owners

3. See Ronald Coase, The Problem of Social Cost, 3 J.L. \& EcoN. 1 (1960).

4. P. 2.

5. Id.; see Coase, supra note 3 , at $2-8$.

6. P. 4.

7. P. 5.

8. P. 4. At some points in the book, Ellickson suggests that the law does seem to affect informal orderproducing processes. See infra text accompanying notes 98-101 for his theory of "feedback loops" between law and other sources of order.

9. Pp. 4, 137-47; see John Griffiths, What is legal Pluralism?, 24 J. LEGal PLURALISM 1 (1986) (contrasting "legal pluralism" with "legal centralism") (revised version of paper presented at 1981 annual 
of Shasta County turn to informal norms rather than legal rules in order to shape social order and resolve disputes, Ellickson opens the way for a more dynamic account of the production of order by everyday citizens.

However, there are a number of difficulties with the route Ellickson takes away from legal centralism, difficulties which constrain his effort to explain neighborly relations in cattle country. There are also some puzzling silences in his ethnographic research; particularly absent is documentation of the "nonhierarchical processes of coordination" so central to his narrative of order. Nevertheless, his interviews with farmers, ranchers, and government officials sketch a portrait of local practice sufficiently rich to allow for other interpretations, and sufficiently entertaining to engage the non-economist. Indeed, Ellickson's colorful account—of marauding cattle, long-term feuds, and neighborhood petitions to transform legally "open" ranges to "closed" ones-carried me through a far less rich and far less entertaining effort to explain why cattlemen and farmers in Shasta County settle their disputes in a cooperative fashion.

In what follows, I draw on Ellickson's ethnography of cattle trespass to provide a more textured account of order in cattle country, and a more compelling explanation of that order. I begin, in Part $\Pi$, by reexamining the relations among cattlemen and their neighbors and by reformulating his concept of "close-knit" relations in Shasta County. Then, in Part II, I discuss the connection of law to the embedded asymmetries that link ranchers and farmers, and consider the ways that "neighborliness" is produced in these asymmetrical relations. I tell an alternative story of hierarchy and of displacement, as commuters and retirees from urban areas transform the landscape in the foothills of Shasta County and traditionalist cattlemen fight for the survival of the "open range" on which their way of life depends.

Ellickson documents this struggle, but misses its significance. He notes the historical pressure on California legislatures to close the range, a pressure that grew through the nineteenth and early twentieth centuries and culminated in the Estray Act of 1915, which made owners of livestock in most of the state strictly liable for trespass damage. ${ }^{10} \mathrm{He}$ points to the continuing pressure on Shasta and other northern counties to enact similar restrictive legislation. ${ }^{11}$ But he relegates this information to background. This limited use of history follows from Ellickson's ambition to straddle the research fields of law and society, and law and economics. With "one foot firmly placed in each of these two opposing camps,"12 he hopes to provide an anthropologist's account of

meeting of the Law and Society Association, June 12-14, 1981).

10. 1915 CAL. STAT. 636 (current version at CAL. FoOd \& AGRIC. CODE $\$ \S 17001-17128$ (West 1986).

11. P. 43 \& n.12.

12. Pp. 7-8. 
"local knowledge"13 about restraint and the practice of neighborliness, and an economist's explanation for why and when people might prefer "informal" custom to the "formal" rules of law. He suggests that law-and-society scholarship typically provides " 'thick' anecdotal accounts"14 of social control, but lacks a theory of the content of norms. ${ }^{15}$ Research in law and economics, by contrast, is limited by its overly simplistic model of human nature as rational and self-interested in every context. ${ }^{16}$

In sum, Ellickson's explanation of order in Shasta County sets the rational, self-interested homo economicus in a world where nonmarket incentives matter. The problem, as I suggest in Part IV, is that even in this more complex world of neighborly relations, human nature as described by Ellickson remains too simple, too driven by welfare-maximizing incentives. His theory of motivation is still firmly in the economist camp; it can account only for a dispassionate process of calculated decisionmaking. Ellickson's theoretical approach remains distant from the complexities of a world where people are fighting for the survival of a way of life ${ }^{17}$-a world in which choices are not clear and contradictions are irresolvable. As a result, Order Without Law ultimately reduces the vivid moral landscape of Shasta County to a set of subsystems (personal, social, governmental, and so forth) which, while not "entirely distinct" in practice, are theorized as separate spheres. ${ }^{18}$

Ellickson both underestimates the power of law in everyday life and obscures the capacity of ordinary citizens to shape the law. His book's characters are trapped in an idealized sphere of neighborliness that seems strikingly unconnected to the suits, feuds, and complaints that punctuate their stories of cooperation. From Ellickson's own description, it seems to me that it is the complex interpenetration of law with neighborliness that makes the politics of cattle trespass so intense, engaging local officials in problems created by stray livestock "on almost a daily basis,"19 and making at least one of them a "veteran of political disputes over trespassing cattle."20

More generally, a historically grounded approach to human action which examines the specific conditions that compel certain "choices," provides a persuasive alternative to Ellickson's voluntaristic model, in which equal individuals choose what is in their best interest. Order emerges from the

13. P. 7; see CLIFFORD GEERTZ, Thick Description: Toward an Interpretive Theory of Culture, in THE INTERPRETATION OF CULTURES 3 (1973) (arguing that the anthropologist's thick description of culture is interpretive).

14. P. 7 (citing GEERTZ, supra note 13).

15. P. 149.

16. P. 7; see also Robert C. Ellickson, Bringing Culture and Human Frailty to Rational Actors: A Critique of Classical Law and Economics, 65 CHI.-KENT L. REV. 23 (1989).

17. To repeat, Ellickson does present the background and data that lead me to believe that a way of life is at stake in Shasta County, see pp. 116-19; it is his theory that fails to accommodate this central issue.

18. Pp. $130-36,282$.

19. P. 49.

20. P. 35 . 
contradictory wants of people whose ideal of restraint may lead them to cooperate, but whose struggle with the changing "realities of country life"21 (in a place where "country life" has been defined for generations by an economy of cattle ranching) may also lead them to contention, feuds, and the local court.

\section{Closely-KNit HIERARChIES AND FeUdS AS CONTINUING RELATIONSHIPS}

Ellickson's description of neighborly relations in Shasta County begins by drawing some distinctions. The most established residents are the ranchers, whose families have been in the county for several generations and whose large family ranches may be worth more than one million dollars. Ellickson further distinguishes "traditionalist" ranchers, who tend to be less economically successful and let their cattle roam, from "modernist" ranchers, who are economically more prosperous and fence their land. ${ }^{22} \mathrm{He}$ notes that "modernists tend to be younger than traditionalists, have more formal education, and be more active in the Cattlemen's Association."23

Even though these differences among ranchers are important, the major distinction Ellickson draws within what he calls the "close-knit" society of Shasta County ${ }^{24}$ is that between ranchers and ranchette owners. Ranchette owners are generally newcomers to the county; they are "retirees or younger migrants from California's major urban areas." owners reflects both the county's rapid population growth in recent years ${ }^{26}$ and the desirability of the foothill area as a home site because of its relatively cool climate. Ranchette owners, whose properties are generally much smaller than those of ranchers (and some of whom live in mobile homes), "may keep a farm animal or two as a hobby, but few of them make significant income from agriculture."27 Their shallow roots in the area are reflected in ranchers' perceptions that they are "not aware of the natural working order." 28 On the other hand, ranchette owners "admire both the cattlemen and the folkways traditionally associated with rural Shasta County."29

Ranchers and ranchette owners differ not only in the size and type of their real property and in the depth of their knowledge of local ways, but also in the strength of their connections to others in the county. Ranchette owners are at

\footnotetext{
21. P. 54.

22. Pp. 22-25.

23. P. 24.

24. P. 178 .

25. P. 21 .

26. P. 19.

27. Pp. 20-21.

28. P. 64 .

29. P. 21
} 
a disadvantage in mobilizing support from other ranchette owners because few of them have been in the area for long, ${ }^{30}$ and in recruiting cattlemen to their cause because even modernist cattlemen tend to support fellow ranchers in political battles that might lead to increased liability for owners of stray cattle. ${ }^{31}$ Moreover, ranchette owners also lack the established ties to local officials that cattlemen have; officials have dealt with cattlemen regularly over the years and depend on them for positions as county supervisors, brand inspectors, or animal control officers. Finally, they are at a disadvantage because of a historical bias in the California legislature in favor of running cattle at large, the traditional ranching method. ${ }^{32}$ As a result of their relative political isolation, ranchette owners are handicapped in their attempts to influence the give-and-take of daily life in Shasta County, and particularly in their capacity to shape the way neighboring cattlemen control their livestock.

While Ellickson concedes the relative disempowerment of ranchette owners, he nonetheless bases his theory of norms on an argument that these ranchers and ranchette owners in Shasta County constitute a "close-knit group." 33 A close-knit group, according to Ellickson, is nonhierarchical; "informal power is broadly distributed among group members and the information pertinent to informal control circulates easily among them." 34 A close-knit group must also have "credible and reciprocal prospects for the application of power against one another and a good supply of information on past and present internal events." ${ }^{35}$ Thus, close-knittedness is contingent on the existence of continuing relationships among members of the group. ${ }^{36}$ Finally, Ellickson argues that a close-knit group "invariably has exogenous foundational rules, legal or otherwise, that endow and secure basic rights in amounts ample to support voluntary exchange."37

The central thesis of Order Without Law is that "members of tight social groups will informally encourage each other to engage in cooperative behavior." ${ }^{38}$ Ellickson suggests that cooperation maximizes the aggregate welfare of the members of a close-knit group; ${ }^{39}$ oral agreements about constructing fences and informal understandings about how the burdens of fence repair should be borne ${ }^{40}$ are examples of cooperation among rural

30. See pp. 36-37.

31. P. 25.

32. Ellickson notes that California's "pro-cattleman policy grew increasingly controversial as California became more settled and field crops became more common." P. 43; see supra text accompanying notes $10-11$.

33. P. 178.

34. Pp. 177-78; see also pp. 168, 234.

35. P. 181 .

36. Pp. $65-66,168$.

37. P. 174 .

38. P. 167.

39. Id.

40. P. 77. 
residents of Shasta County. The norm that an owner of livestock is responsible for the acts of his animals also exemplifies the "overarching norm of cooperation among neighbors." ${ }^{21}$ In his theoretical evaluation of a norm of cooperation, Ellickson discusses the transaction costs involved in formal contractual agreements and in negligence rules, as well as the benefits of close personal relationships and high social status. His argument about the benefits of cooperation is persuasive, and is consonant with the well-known "continuing relations" hypothesis found in the anthropological literature. ${ }^{42} \mathrm{He}$ is less persuasive when he suggests that rural residents of Shasta County are in fact close-knit, or that they settle disputes cooperatively and beyond the reach of the law.

Who is included in cattle country's close-knit group? All ranchers? Traditionalist ranchers? Ranchers and ranchette owners? Ranchers and county officials? Everyone involved in transactions around stray cattle? Ellickson at times seems to suggest that even the motorists who occasionally collide with stray cattle on highways that run through cattle country are part of the transacting "group" within which cost-minimizing norms allocating responsibility for damage are developed..$^{43}$ The problem with an analysis that focuses on bounded groups, as Order Without Law does, is that it must then specify which incidents, disputes, and communications are "internal" and which are "external" to the group in question. The criteria Ellickson proposes for distinguishing "close-knittedness"-adequate information, reciprocal power, and ready sanctioning opportunities ${ }^{44}$-require details about how information circulates and who has access to it, and Order Without Law presents only very sketchy ethnographic data from which conclusions might be drawn about these questions. ${ }^{45}$ We learn quite a lot about the continuing relations of traditionalist cattlemen, antitraditionalists, and county officials, ${ }^{46}$ and about the capacity of these actors to bring pressure to bear on one another. But these

41. P. 53.

42. For statements of the "continuing relations" hypothesis, see, e.g., DONALD BLACK, THE BEHAVIOR OF LAW 41 (1976); MAX GLUCKMAN, THE JUdiCIAL PROCESS AMONG THE BAROTSE OF NORTHERN RHODESIA (ZAMBIA) 20-24 (2d ed. 1967); Laura Nader, Styles of Court Procedure: To Make the Balance, in LAW IN CULTURE AND SOCIETY 69, 86-90 (Laura Nader ed., 1969). For reexaminations of the hypothesis, see, e.g., June Start \& Barbara Yngvesson, Scarcity and Disputing: Zeroing-in on Compromise Decisions, 2 AM. ETHNOLOGIST 553 (1975); Barbara Yngvesson, Re-Examining Continuing Relations and the Law, 3 WIS. L. REV. 623 (1985); Symposium: Law, Private Governance, and Continuing Relationships, 3 WIS. L. REV. 461 (1985).

43. Though he emphasizes that motorists are relatively incapable of collective action. P. 187 .

44. P. 181 .

45. For example, Ellickson mentions gossip as a source of information and a method of sanctioning in rural Shasta County, but the evidence he offers is anecdotal, consisting of general comments about how people "gossip all the time," or of self-reports about gossiping. Pp. 57-58. Ellickson accepts uncritically the notion that "negative gossip helps prompt its target to square accounts," p. 214, and that "gossip must be truthful," p. 215. He does not question whether gossip actually functions in the way that his informants say it does, and does not consider that gossip may tell us more about the features of a moral landscape, and how people are positioned and repositioned within it, than about actual strategies of social control.

46. Pp. 29-64. 
pressures include lobbying, lawsuits, petitions, and feuds, as well as the friendly calls and cooperative fence-building that Ellickson's theory of norms emphasizes. The notion that the "ongoing multifaceted relationship" of these actors catches them in a "civilizing grip"47 that "glue[s]"48 them together in relations of neighborliness is particularly dissonant in light of the details Ellickson provides on the politics of cattle trespass and on the resolution of cattle trespass disputes. ${ }^{49}$

Ellickson's description of the relations of ranchers to ranchette owners, and of traditionalist to modernist ranchers, is reminiscent of other ethnographic literature about hierarchical and competitive relations among "newcomers" and "oldtimers" in American towns. ${ }^{50}$ Relationships in Shasta County have existed for varying amounts of time. Some ranchers have been in the area for decades and are descendants of pioneer ranching families; some ranchette owners arrived only a few years prior to Ellickson's research in 1982. Whether the relationships are longstanding or new, what most of the ethnographic detail in Ellickson's book suggests is that they are cast (and continually recast) along lines that divide "a traditional agrarian order" from "an emerging urban rival." The rivalry revolves around the question of "who has what place in the sun" in rural Shasta County. ${ }^{52}$

For example, efforts to change the legal regime of Shasta County from open to closed range ${ }^{53}$ are part of a struggle between traditionalist and modernist cattlemen, carried out in legal and other political arenas, about whether traditionalist cattlemen are still "king" in one of the few remaining open range regions of California. ${ }^{54}$ This struggle for dominance goes back to the late nineteenth century; it continues not only in fights over which legal

47. P. 66

48. P. 236.

49. Pp. 29-64.

50. See, e.g., Carol J. Greenhouse, Barbara Yngvesson \& David M. Engel, Contest and COMMUNITY: THE MEANINGS OF LAW IN THREE AMERICAN TowNS (forthcoming 1993); Engel, supra note 2. Ellickson notes in passing the relatively greater tendency of newcomers outside of Shasta County to use the legal system, as documented, for example, by David M. Engel, Cases, Confict, and Accommodation: Patterns of Legal Interaction in an American Community, 1983 AM. B. FoUND. RES. J. 803, 820-21 (cited by Ellickson at p. 182 n.48). But he does not connect this observation to the behavior of his own "newcomers," nor does he examine the difficulties posed by "newcomers" to any analysis that describes relations as "close-knit" and "nonhierarchical." He simply suggests that there may be variations in the "intimacy" and the "continuity" of relations in close-knit groups. Pp. 180-81. While this is indisputable, the meaning of these variations in any given locale must be examined. The perception that some recent arrivals (and even some less recent arrivals) in Shasta County are "not aware of the natural working order," p. 64, suggests that variations of intimacy and continuity may be connected to a moral hierarchy. This moral hierarchy is documented in other ethnographic work on the United States; its existence in Shasta County is revealed in discussion of the "restraint" attributed to established ranching families, who are "particularly intent on maintaining their reputations as good neighbors." P. 57; see Carol J. Greenhouse, Signs of Quality: Individualism and Hierarchy in American Culture, 19 AM. ETHNOLOGIST 233 (1992).

51. P. 117.

52. Id.

53. Pp. 29-39, 104-120; see supra text accompanying notes 10-11.

54. Pp. 43, 234. 
regime applies, but in controversies between farmers and cattlemen about animal trespass and "lawful fences." relationship in the county, a feud involving traditionalist rancher Frank Ellis, who moved to Shasta County in 1973, and ranchette owner Doug Heinz, who moved to the county in $1978 .^{56}$

The precipitating factor in this feud was the repeated damage to Heinz's property caused by Ellis' livestock. Heinz is described by Ellickson as aspiring to "small-scale squiredom,"s7 and Ellis is noted for his "ruthless ambition for wealth and power." 58 During the late 1970's, Ellis had built up the largest ranching empire in the county; by 1981 , he was "aggressively running a herd of two to three thousand cattle at large in the grasslands and lower foothills northeast of Redding." 59 Ellis became the target of numerous lawsuits and had an attorney on retainer. In the course of his feud with Ellis, Heinz threatened to kill Ellis' cattle, called the sheriff, and petitioned the Board of Supervisors along with "dozens of ranchette-owning newcomers, as well as members of at least one respected and long-established ranching family in the Oak Run area." ${ }^{\prime 60}$ During the winter of 1981-82, these activities produced what Ellickson describes as a "battle of petitions"61 among residents of the Oak Run area where Ellis ran his cattle. The controversy was ultimately mediated by a member of the Board of Supervisors, a government agency which traditionalist cattlemen "fear ... more than they fear law enforcement authorities." ${ }^{162}$ Ellis was eventually persuaded to fence part of his land, but only after the county animal control officer, the Shasta County Cattlemen's Association, and the Board of Supervisors had become involved.

This lengthy feud, and the fissures it reveals in the close-knit society of Shasta County, is explained by Ellickson as a deviation. "[N]either the trespass victim nor the cattle owner was a practiced follower of rural Shasta County norms. Thus other respondents tended to refer to ... [them] as 'bad apples,' 'odd ducks,' or otherwise as people not aware of the natural working order." ${ }^{63}$ Ellis is described as a man who "came to personify the evils of a lack of neighborliness." ${ }^{64}$ By marginalizing the misdeeds of "bad apples" as deviant, and by similarly casting certain legal actions of good apples (such as

55. A "lawful fence" has "three tightly stretched barbed wires securely fastened to posts of reasonable strength, firmly set in the ground not more than one rod [16 and a half feet] apart, one of which wires shall be at least four feet above the surface of the ground." P. 45 n.24 (quoting CAL. FOOD \& AGRIC. CODE $\S$ 17121 (West 1986)).

56. Pp. 33-39.

57. P. 34.

58. P. 33.

59. P. 34.

60. P. 35 .

61. Id.

62. P. 60 .

63. P. 64.

64. P. 234. 
Supervisor John Caton), who "shared many of the cattlemen's values," blunders or "foll[ies]," Ellickson underplays the significance of conflicts such as these to the construction and maintenance of order in cattle country.

The prominence of these disputes and feuds in the first chapters of Order Without Law suggests that the "natural working order" is precisely what "odd ducks" such as Heinz, Ellis, and other disputants are fighting about; their fights are one of the ways in which the order of traditionalist cattlemen is contested by modernists and ranchette owners. These contests are fought primarily with petitions and threats, but they remain well within the reach of the law in their involvement of county supervisors ("the person best situated to change straycattle liability rules"), ${ }^{67}$ animal control officers, or brand inspectors, and in their occasional enactment as legal claims in court. For example, Bob Moquet and his brother, both defined as traditionalist cattlemen, filed numerous complaints in small claims court against motorists who killed their livestock, seeking compensation for the dead cattle. ${ }^{68}$ Ellickson again suggests that Moquet was "a deviant from prevailing rural norms," that the small claims suits were not entirely inappropriate because they were brought against "strangers from another subculture" (that is, truckers). ${ }^{70}$ But Ellickson also notes that "the small claims carried a lot of symbolic freight for the traditionalists" and that they "enabled the traditionalists to test and possibly shape ... . [a] new judge's attitude toward the legitimacy and symbolic importance of the traditionalist mode of cattle husbandry in the Northeastern Sector foothills."71 The marginalization of "odd ducks" such as Ellis is also extremely important, symbolically, for traditionalists, whose "place in the sun" is secured not only by their success in lobbying for open range ordinances, but also by their continuing ability to position themselves at the pinnacle of a culturally-sanctioned moral hierarchy that values neighborliness.

By reading the neighborly order of Shasta County as beyond the reach of the law, Ellickson misses the dynamic relationship between law, disputing, and neighborly order. By accepting the statements of cattlemen that their fellows who go to court are in effect outside a close-knit group (that is, that they are "bad apples"), he obscures the place of feuding in the construction of closeknittedness. He never asks the crucial question: what can disputes tell us about the moral and political landscapes of Shasta County? If we accept that disputes might help produce order rather than promote its breakdown (or, at best, deviate from the orderly norm), we secure a vantage point for examining how

65. P. 32.

66. $I d$.

67. P. 60.

68. Pp. 101-02.

69. P. 31 n.7.

70. P. 102.

71. Pp. 102-03. 
these moral and political landscapes are created and maintained by ordinary citizens, in Shasta County and elsewhere.

\section{The Legal REgIME OF OpEN RANGE}

What Ellickson fails to appreciate is the connection of the legal regime of open range to the neighborly order of "lumping" (that is, absorbing the damage from) trespass incidents. ${ }^{72}$ Open range entails a very narrow interpretation of legal trespass as well as a broad interpretation of "inevitable" injurious events, ${ }^{73}$ it is maintained through the powerful lobby that connects traditionalist cattlemen to county officials. ${ }^{74}$ County officials thus play a key role in the neighborly order of Shasta. Mostly, they discourage the "victims" of trespass incidents from pursuing a claim, by means of talk about "cattlemen's open-range rights." ${ }^{\text {"75 }}$ Sometimes, however, they wield their legal power to close the range, in response to pressures from ranchette owners and motorists. ${ }^{76}$

While Ellickson accepts as unproblematic the neighborly "norm" that minor damage from alien animals is "not . . . an injurious event but ... an inevitable part of life,"77 he also describes such incidents as "trespass" as "internal disputes," "79 and he interprets the failure of cattlemen to respond as part of a practice of self-imposed "restraint" that minimizes transaction costs for this close-knit group. ${ }^{80}$ Order Without Law does not systematically explore the circumstances under which noninjurious events escalate into public dispute. $^{81}$ Ellickson relies on interviews with landowners, and particularly with specialists such as attorneys, government employees, and insurance claims adjusters, for his data on trespass incidents and local norms, ${ }^{82}$ but we need still more information on the role of local officials in the transformation of incidents into perceived injuries and of perceived injuries into occasions for

72. P. 54.

73. Id.

74. Pp. $35-36$.

75. Pp. $47-48$.

76. P. 35; see also discussion of Caton's Folly, pp. 30-32.

77. P. 54 .

78. Id.

79. P. 251.

80. Pp. 172-73.

81. On this issue, see Lynn Mather \& Barbara Yngvesson, Language, Audience, and the Transformation of Disputes, 15 LAW \& SOC'Y REv. 775, 776 (1980-81), in which we argue that disputing is a dimension of a social relationship, that disputes emerge over time in political contexts, and that disputes must be distinguished from grievances or other forms of dyadic confrontation. In a related vein, Felstiner, Abel, and Sarat argue that disputes must not be confused with "unperceived injurious experiences," which may or may not be transformed into formal litigation. William L.F. Felstiner et al., The Emergence and Transformation of Disputes: Naming, Blaming, Claiming ..., 15 LAW \& SOC'Y REV. 631 (1980-81).

82. Pp. 40 n.l, $291-92$. 
restraint. Ellickson provides provocative but sketchy accounts of this process, ${ }^{83}$ preferring to focus on local gaps in legal knowledge that these interventions reveal, and on gaps in ordinary people's understanding of the formal law of trespass and of fencing ordinances. ${ }^{84}$

These technical differences between law and local norms are perhaps of interest to a legal audience used to thinking in terms of Coase's "Parable of the Farmer and the Rancher." 85 What is far more striking to me, as an anthropologist, is how "rights talk" and the shadow cast by potential legal action set the parameters that turn some incidents into "trespass" and others into "the realities of country life." This shadow is clearly visible in the words and actions of official agents in Shasta County such as John Caton (a member of the Board of Supervisors), Brad Bogue (the animal control officer), ${ }^{86}$ and Bruce Jordan (the brand inspector). ${ }^{87}$

Understanding how residents view trespass incidents is complicated by an issue Ellickson does not address-whether courts actually would penalize the instigators of many of the incidents that he describes as legal "trespass." 88 Most of the disputes among neighbors Ellickson describes in his second and third chapters resemble matters that are informally classified by many courts as "garbage" cases. ${ }^{89}$ "Garbage" cases typically involve people whose relationship is perceived as ongoing (family members or neighbors, for example), and behavior described by court staff as "everyday" (harassment, threats, punching, shoving). ${ }^{90}$ People who wish to complain of such matters may file criminal complaints with a magistrate, ${ }^{91}$ seeking, for example, the preferment of criminal charges of trespass, malicious destruction, or assault. (Depending on the jurisdiction, court clerks or judges sit as magistrates over such applications). Complainants may also attempt to persuade a prosecutor to file charges. In general, however, courts treat these complaints as "nuisances," ${ }^{92}$ and tend to dismiss them or divert them to mediation. ${ }^{93}$ These kinds of cases may also occasionally be filed as civil complaints, but civil litigation is costly to the complaining party, and small-scale feuds are not attractive to attorneys.

83. See, for example, his discussion of threats by the animal control officer to impound offending animals, or by the brand inspector to invoke formal law during the mediation of disputes, pp. 47-49, and of calls by ranchette owners who have suffered a "trespass incident" to county officials, pp. 59-60.

84. Pp. 50, 68, 70, 72. Ellickson is equally interested in the imperfect legal knowledge of specialists such as attorneys, judges, or insurance claims adjusters. P. 49.

85. See supra notes 3-5 and accompanying text.

86. Pp. $47,49$.

87. P. 49.

88. Ellickson discusses trespass and formal legal entitlement to compensation at pp. 40-48. 414.

89. See Christine B. HARrington, SHADow JustiCE 146-49 (1985); Yngvesson, supra note 2, at

90. HARRINGTON, supra note 89, at 146-49; Yngvesson, supra note 2, at 414, 420-41.

91. See, e.g., CAL. PENAL CodE $\S 806$ (West 1986).

92. HARRINGTON, supra note 89 , at 146.

93. Id. at 145-46; Yngvesson, supra note 2, at 421 \& n.19. 
The Ellis-Heinz feud described by Ellickson is typical of the disputes that become "garbage" cases. Neither party attempted to bring the case to criminal court, but Heinz did file a civil suit. The relatively low economic value of this action is suggested by its eventual settlement; Ellis paid Heinz $\$ 300$ in damages and $\$ 100$ in attorney's fees. ${ }^{94}$ In general, it seems that the absence of litigation over trespass incidents in Shasta County, whether in criminal or civil court, may not simply be a result of a norm of neighborliness. Rather, aggrieved parties may have few options but to "lump" their losses: in criminal court, complaints of threats and trespassing would likely be dismissed as "garbage"; in civil court, the filing fee and other costs of litigation might discourage less affluent complainants, such as the economically marginal ranchette owners, from filing a suit whose economic value is likely to be low.

These considerations mean that it is difficult to draw clear boundaries between the "inside" world of neighborliness and the "outside" world of state law. ${ }^{95}$ Ellickson encounters similar difficulties in his discussion of how ordinances that close the range affect traditionalists' practices of running cattle, and in his discussion of how pressure by a public official on a traditionalist rancher to build a "lawful fence" comes to symbolize neighborly cooperation. ${ }^{96}$ Similarly, Ellickson's discussion of the symbolic importance of legal claims by traditionalist ranchers against motorists (seeking compensation for cattle injured by highway collisions) points to the connections between law and local norms. ${ }^{97}$

Ellickson attempts to accommodate the slippage between informal rules and law by including "feedback loops" in his theory of norms. Because his model of human behavior posits that people are positioned at the intersection of different spheres of rules (personal ethics, contracts, norms, organization rules, and law), he must explain the influence of one sphere on another. He writes that feedback loops "harmonize the rules of different controllers," that is, of the different sources of behavioral rules and the sanctions that back up

94. See pp. 34-35, 63-64. For a comparable feud in rural New England, see Yngvesson, supra note 2 , at $426-32$.

95. See, for example, Ellickson's description of "the informal resolution of internal disputes." P. 251; but see pp. 254-56 (on "mixing the informal and legal systems").

96. Pp. 45, 112. See supra note 55.

97. Pp. 102-03. Outside of Shasta County, Ellickson presents a compelling account of these connections in a discussion of the whaling industry from 1750 to 1870. P. 191-206. During this period, the informal practices of whalers regarding ownership of a contested whale carcass were accepted by judges, who "regarded themselves as bound to honor whalers' usages that had been proved at trial." P. 196. Curiously, Ellickson's research reveals that the most complete evidence for these informal practices is contained in court records. He does not share my sense that these sources are themselves evidence suggesting the "informal" norms were constructed in the context of legal disputes. For a comparable example of the construction of culture in court, see JAMES CLIFFORD, Identity in Mashpee, in THE PREDICAMENT OF CULTURE 277 (1988), which describes the suit by the Mashpee Wampanoag Tribal Council for possession of several thousand acres of land on Cape Cod. The Council was compelled to prove that the Mashpee shared a tribal identity, as represented by traditional practices that distinguished their lives and customs from those of the dominant culture. 
those rules. ${ }^{98}$ But he argues that "the loop from law to norms is not sufficient to make norms invariably converge toward law in all contexts." ${ }^{99}$ Rather, legal rules may influence social structure in such a way that the possibilities for informal cooperation are enhanced. ${ }^{100}$ In addition, Ellickson proposes that individuals "mix" legal and informal social controls "in sophisticated ways" that are welfare-maximizing. ${ }^{101}$

\section{NORMATIVE THEORIES AND RELATIONAL THEORIES}

Ellickson relies on this unwieldy process of connected rules to explain how human society orders itself. This reliance is necessary because he adopts the very model of human nature that he criticizes as limiting the vision of his economist colleagues. ${ }^{102}$ Economists ordinarily understand people as isolates, entering into relations with others only to maximize their own welfare. The transactions in which they engage are secured by "exogenous foundational rules,"103 that is, rules like those against murder or enslavement, rules to protect property interests, and so forth. Ellickson's vision of foundational rules is broader than that of most legal centralists and economists, but the difference is one of degree, not kind. His decentralized model of society simply multiplies the sources of foundational rules: he supplements the concept of a Leviathan by commenting that "every person has an inherent endowment of brainpower and musclepower, and also an instinct of self-preservation," noting as well the "[h]uman instincts of kin preservation," and arguing that together these natural endowments produce the order-creating ability to threaten retaliation. ${ }^{104}$ Similarly, he supplements the property entitlements secured by the state with "anarchic creation of property rights." 105 According to Ellickson, these basic entitlements make possible the "voluntary exchanges" out of which order is constructed. Everyday social life is reduced to a calculus of welfaremaximization, carried out in the shadow of some set of rules, "legal or otherwise." 106 Ellickson's theory posits somewhat more complex actors than the farmer and the rancher of Coase's oft-cited theorem, since his cattlemen operate in the shadow of multiple sets of norms, rather than simply in the shadow of the law. ${ }^{107}$ But ultimately he offers us only a souped-up version of economic man, mired in rules (natural, personal, social, governmental), and

98. P. 132 (on feedback loops); see also pp. 126-31 (on controllers).

99. P. 282.

100. P. 284.

101. P. 254 .

102. P. 7.

103. Pp. 174-76.

I04. Pp. 173-74 n.23.

105. Id.

106. P. 174.

107. P. 131 . 
in "feedback loops" intended to explain the mutual effects of rules in a world where the "social," the "personal," and the "governmental" are seen as developing essentially in isolation from one another. ${ }^{108}$

But the actual lives that Ellickson documents do not take place in separate spheres. Whether lobbying for an open range, filing petitions to close it, calling a neighbor about his marauding cattle, seizing each other's cattle, bringing claims to court, or advocating neighborliness, people exist in a world where law and neighborliness cannot coherently be conceptualized as separate. By focusing on the actions and relationships of county residents, we can gain an understanding-as Ellickson aspires to do- of how order emerges from the transactions of everyday life. But to do so we must move away from an understanding of motivation as rational, welfare-maximizing, and dependent on foundational rules, of whatever kind. Instead, we should turn to local histories and the embedded hierarchies these reveal for a contextualized account of human motivation, whether in cattle country or elsewhere. ${ }^{109}$ These hierarchies connect people in ongoing relations of dependence and obligation that define the entitlements of some and the offenses of others; it is in these hierarchies, and the emotional struggles they produce (rather than in the rational transactions of autonomous individuals, secured by foundational rules) that the sources of motivation should be sought. ${ }^{110}$ The entitlements and offenses shaped by historical relations of hierarchy are not "exogenous" to everyday relations, but are produced in them, just as cattlemen and farmers have produced and are producing the legal regime of the county in their "Battle of Petitions" $" 11$ over the closing of the range. The historical contingency of these relations does indeed mean that there is an "occasional indeterminacy"112 in our explanations, but this is surely no cause for alarm. Rather it should be an occasion for hope that established hierarchies and inequities that seem to be "exogenous" may be transformed, over time, in the contests of everyday life.

108. Pp. 131-32; see also pp. 254-56.

109. Such an inquiry is attempted in Maureen A. Mahoney \& Barbara Yngvesson, The Construction of Subjectivity and the Paradox of Resistance: Reintegrating Feminist Anthropology and Psychology, 18 SIGNS 44 (1992).

110. For a discussion of the relational theory of motivation, see id.; see also D. W. WINNICOTT, The Theory of the Parent-Infant Relationship, in THE MATURATIONAL PROCESSES AND THE FACILITATING ENVIRONMENT 37 (1965).

111. P. 35.

112. P. 175 n.27. 
